\title{
Vaginal Squamous Neoplasm
}

National Cancer Institute

\section{Source}

National Cancer Institute. Vaginal Squamous Neoplasm. NCI Thesaurus. Code C40242.

A benign or malignant neoplasm that arises from the squamous epithelium of the vagina.

Representative examples include condyloma acuminatum, squamous papilloma, and squamous cell carcinoma. 